\title{
Chapter 14 \\ Coevolution of Town and Gown: The Heidelberg International Building Exhibition in Search of a Knowledge-based Urbanism for the Twenty-first Century
}

\author{
Carl Zillich
}

The evolution of cities has always been closely linked to political, social, and economic ideas of the time. Often, forces reflecting the resulting paradigms, such as the "car-friendly city" of the second half of the twentieth century, shaped the spatial configuration of urbanization. The Heidelberg International Building Exhibition (IBA) has set out to present solutions that mirror and foster what is called the knowledge-based society through processes and projects of city planning, urban design, and architecture by $2022 .{ }^{1}$ The focus on knowledge and space is consistent with the coevolution of the city and its university and of its other research institutions thus far. For more comprehensive, integrated, and proactive solutions than every-day governance can deliver, the municipality chose the strategic process of an IBA, relying on a German tradition of experimental case studies in and with the built environment (Stadt Heidelberg, 2012).

\footnotetext{
${ }^{1}$ Whereas the evolution of cities has always been based on knowledge, the knowledge-based society has induced a more inclusive urban design on multiple scales. In acknowledgment of both the separation of functions in the modern city and the ever-increasing disciplinary fragmentation of knowledge, a new paradigm for the spatial production of our city is on our agenda, one that inspires exchange between, innovation in-between, and integration of formerly separated disciplines, milieus, and spaces. See http://www.iba.heidelberg.de.

C. Zillich (ه)

International Building Exhibition, IBA Heidelberg GmbH, Heidelberg, Germany

e-mail: c.zillich@iba.heidelberg.de
} 


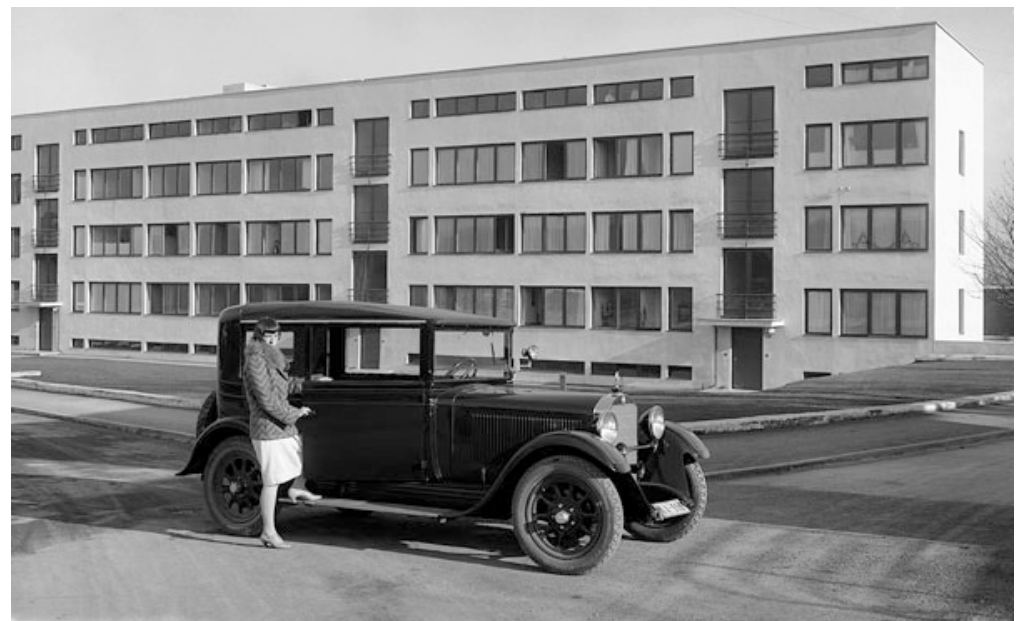

Fig. 14.1 Avant-garde housing by Ludwig Mies van der Rohe in the 1927 Weissenhof Siedlung in Stuttgart was used as an iconic background for the Mercedes-Benz limousine type 8/38 PS in 1931. The challenge of conceptualizing spatial opportunities for things to come seems more difficult a century later, with science and technology supersede human physical reality.

Source: Picture Archive Daimler AG. Copyright: Daimler AG. Reprinted with permission.

\section{Germany's IBAs}

\section{Years of IBA Experience}

From the outset the strategies of the IBAs have been adapted to the societal system in which the IBAs were based, but they have always been about implementing or building the next spatial practice over a period of years, often a decade. For example, the detailed history of IBAs in Germany by the architecture historian Werner Durth (2010b) has identified the Mathildenhöhe in Darmstadt as the first comprehensive approach to integrating design ambitions with a "life reform movement." In 1901 Grand Duke Ernst Ludwig (1868-1937) and his master architect, Joseph Maria Olbrich (1867-1908), achieved the integration of art, craft, and life with an art nouveau campus and buildings that provided spaces for exhibitions, studios, and housing.

Whereas this endeavor ran counter to the industrial revolution that changed society at large, subsequent IBAs embraced those forces. Under the urban design and artistic guidance of Ludwig Mies van der Rohe (1886-1969), avant-garde architects from all over Europe were invited to design the Weissenhof Siedlung in the outskirts of Stuttgart. There, in 1927, a testimony of "New Building" delivered new typologies in housing with building technologies and aesthetic coherence revolutionary in scope (Fig. 14.1). Berlin followed up by using the IBA strategy twice to deal with very different challenges under different circumstances. In the 1950s both East and West Berlin adopted large-scale urban renewal schemes to 
showcase their capacities to envision cities for different futures. East Berlin unveiled "palaces for the people" on Stalinallee in 1952, and West Berlin presented what was called the "Interbau" in the Hansaviertel, where planners and architects from across the world fulfilled a modernist dream of living in an urban landscape of dwellings with innovative layouts.

By 1987 the opposite paradigm was implemented when Berlin's old structures in Kreuzberg were either repaired, often with the engagement of the inhabitants, or rebuilt by young architects, mostly from abroad, who experimented with contemporary concepts of design. The social dimension of architecture and urbanism was further developed in a larger context in the deindustrialized context of the Ruhr District. In 1999 a regional network of strategic brownfield developments with housing and service industry was presented. It marked a turnaround for a declining agglomeration and transformed industrial ruins to monuments. This incomplete overview of the IBA ends with the city of Hamburg, which used a holistic approach far beyond spatial terms to guide the transformation of Wilhelmsburg, an island in the Mitte district at the mouth of the Elbe. Addressing education, infrastructure, energy supply, and other issues, the project worked on different scales with a balance of top-down and bottom-up tools for planning a city fit for the future.

\section{State of the Art: The IBA Today}

Although an IBA is not certified or licensed or guaranteed any funding, around 2010 a federal commission developed criteria for ensuring a level of discourse and quality (Durth, 2010a). An informal network of past, current, and future IBAs now aims to take standards of excellence derived from the past and strike a balance between them and necessary evolutions in processes and implementation that respond adequately to challenges of today. Projects should be about

1. linking society's evolution and spatial development;

2. addressing not just innovation in architecture but also new concepts of urban space;

3. deriving the agenda from local or regional necessities;

4. developing prototypical solutions to address spatial, economic, ecological, and social aspects;

5. linking excellence in built projects to adequate processes and procedures;

6. maintaining an international dimension from the outset through projects on-site and relevance abroad;

7. establishing exceptional conditions for the duration of an IBA by providing a cross-disciplinary laboratory and by pooling resources;

8. bringing all participants to agree that the IBA, as an experiment based in reality, requires all involved to take risks and be courageous; and

9. finding an appropriate structure for imagination and challenging established procedures. 
These rather soft criteria show acceptance that architecture and the society it reflects have changed radically over the last century. Although developers and politicians desire certification in architectural production, it does not help spearhead innovation. The intention of the federal commission is therefore to give guidelines for the excellence of an IBA without requiring it to reinvent itself anew in every locality and context. An IBA today is about the urban realm and its underlying governance as much as about architecture and its aspects of function and representation.

\section{The Question Concerning Heidelberg}

\section{Discursive and Specific}

For the first time in the post-World-War II era, an attempt is underway to make an IBA proactive. With the whole city as its testing ground and no urgent problem crying out for urban renewal, the quest for an intensified knowledge-based urbanism has begun. The discourse on the service economy and its shift from dynamic capital and predefined labor to dynamic knowledge and self-organization has been heard for some time, but the resulting potentials or prerequisites for the production of space in terms of architecture and urban design have received little attention. Responding to new working environments that are evolving around the digital economy and networks and to the growing interest in built space as the third teacher or educator ${ }^{2}$ (Hubber \& Ramseger, 2017, p. 58; see also Malaguzzi \& Cagliari, 2016), a discussion has begun in which Heidelberg offers the testing grounds to focus, connect, and offer new solutions on different scales. As a medium-sized city with excellent universities, Heidelberg represents a "knowledge pearl" (Van Winden, Van den Berg, \& Pol, 2007, pp. 540-542) and is thus predestined for reevaluation of the relationship between a city and the production and distribution of knowledge.

As the site of Germany's oldest and most prestigious university as well as numerous international scientific research clusters and institutions (e.g., the European Molecular Biology Lab, four different Max-Planck-Institutes, the German Cancer Research Center, the Heidelberg Institute for Theoretical Studies and others), Heidelberg is embedded in a region of strong global players (e.g., BASF, Freudenberg, and SAP). The question is how the city of romanticism can also become a contemporary city of knowledge, not just substantively but also spatially. Such a transformation could help its population build on today's traditions and strengths to be fit for a future of ever-growing competition, especially with knowledge hubs like Berlin, London, Paris, New York, and Silicon Valley.

\footnotetext{
${ }^{2}$ Adults and children are the first two teachers.
} 


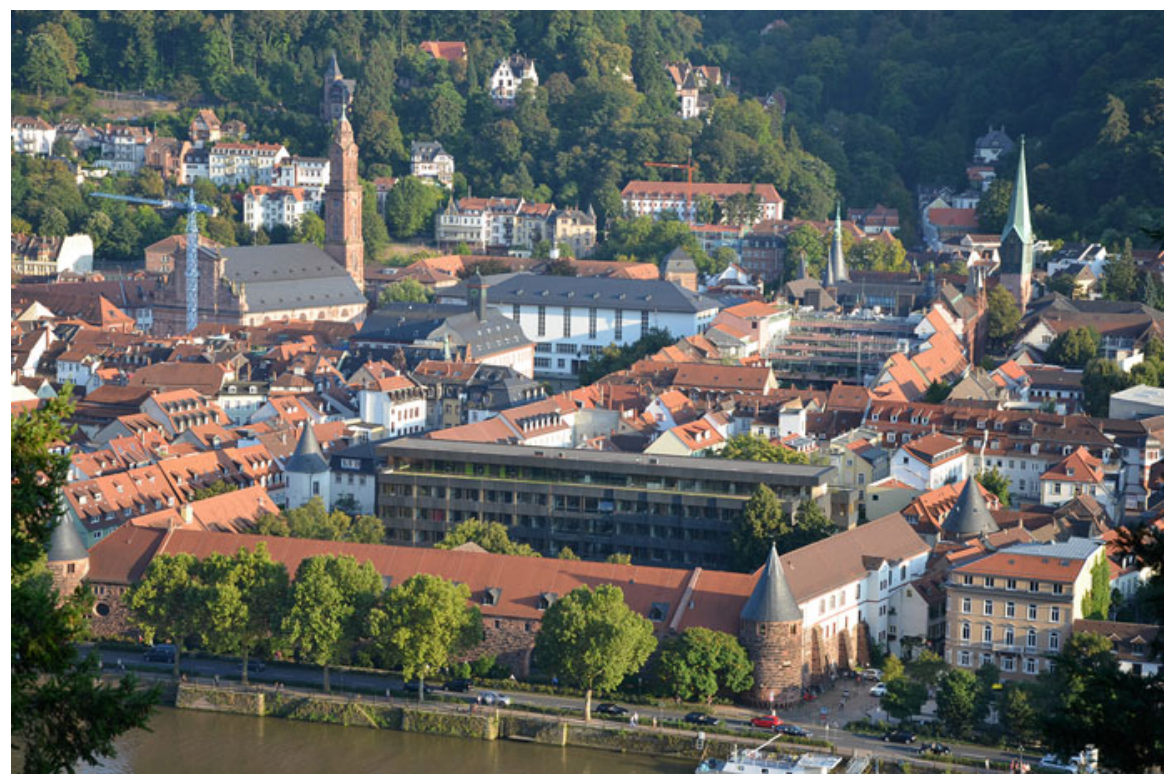

Fig. 14.2 Large administrative and faculty buildings of Heidelberg University, such as the Old University (1735), the New University (1931), and the Neues Kollegiengebäude (1965), alter the urban fabric of the Old Town. Debate continues about the direction in which the next leap forward is to go (e.g., the urbanization of monofunctional campuses?).

Source and copyright: Carl Zillich.

\section{Coevolution of Town and Gown}

Heidelberg manifests a clear sequence in the coevolution of the city and its university (Matthiesen, 2015). Each sequence has a different typology of how university and city are intertwined, also reflecting the town-and-gown relationship from which its spatial configuration resulted. The first spatial refuge of the evolving sciences was in bourgeois mansions, which spread westward below the castle. In the stage thereafter, with its Old University (a building from 18th century) and then with increasingly specialized buildings within the boundaries of the Old Town (Fig. 14.2), the university became a driving force behind claims on new lands beyond the already urbanized territory. Technical imperatives and the drive for specialized buildings found expression in a succession of architectural eras, beginning with the hospitals in Bergheim and eventually the accommodation of the natural sciences across the Neckar river in Neuenheimer Feld. This sequence has continued into the present, with independent research facilities being located on the hillside and recent attempts being undertaken to establish a research agglomeration on brownfield developments south of the central railway station as part of the new Bahnstadt. Rearrangement across different campuses of Heidelberg University since 2009 has 
had social sciences replace clinical functions in Bergheim, which are being concentrated north of the river, with great potential for both neighborhoods.

For the IBA this coevolution of university and city exemplifies the claim in knowledge-based urbanism that each phase of development brings about a different identity, often through ambitious architecture. Yet a closer look reveals that the quality of public spaces and the possibilities for interdisciplinary and even nonacademic encounters have been gradually diminishing. Mixed-use developments, spaces for interaction and identification, integrated planning of open spaces, and integrated planning of traffic infrastructure are four layers for possible IBA engagement in this realm.

\section{Agents of Change}

Based in reality as a living lab fostering research by means of design, the Heidelberg IBA is a forum for initiating processes and inviting agents of change to join in the search for a next practice in governance of spatial production. In addition to the need to prepare for upcoming requirements in research and development and in education for an inclusive society, two particular interests have emerged over the first few years of the Heidelberg IBA. One is the infrastructure of everyday life. How do people connect the different knowledge hubs in and beyond Heidelberg, and what potential lies in public spaces, old and new, for an open and interactive society? The concepts range from express-bike paths to experimental design of the urban landscape. Other issues of today's city metabolism, or urban modes of exchange, range from biodiversity to urban agriculture and their potential for education, health, and leisure.

\section{The Heidelberg Case and Its Strategies}

\section{Communication and Inspiration}

Working on the invisible and built aspects of education, research, and development, the IBA is a platform, think tank, and start-up agency at once. Its work is therefore based on discourse and communication within different formats for different clienteles established in the first two years.

As part of a double strategy for gaining in-depth knowledge about Heidelberg and conveying the message by looking at each neighborhood anew, events known as IBA_LOCAL attracted 80 to 120 people on various Saturday afternoons. In eight dialogical walks inspired by what Burckhardt (2015) called "strollology," spatial experts foreign to Heidelberg talked with local stakeholders and IBA officials about what sites of knowledge exist in this city already, how they work, and what spaces are felt to be missing (see Figs. $14.3 \&$ 14.4). 


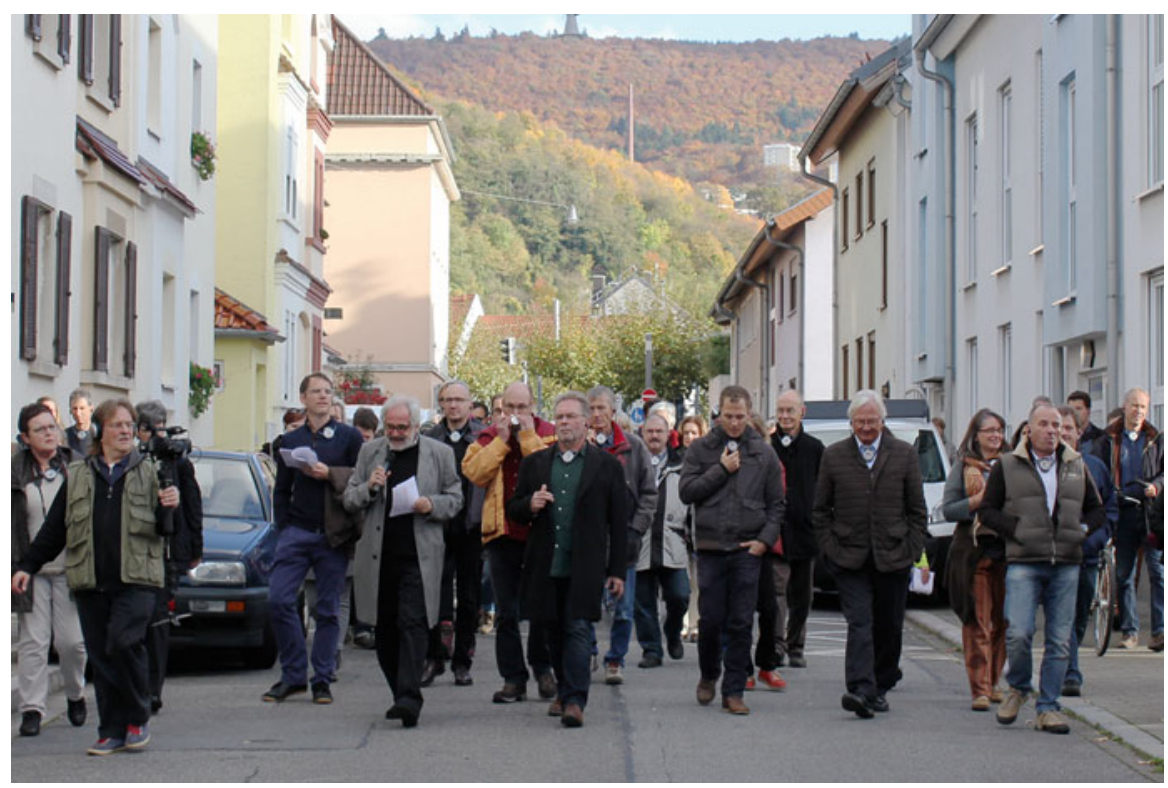

Fig. 14.3 IBA_LOCAL, No. 7-A dialogical stroll through the neighborhoods of Rohrbach (picture) and Kirchheim on November 7, 2014, to address the identified qualities and future potential for spaces of and for knowledge. Official partners of this particular public discourse were Ursula Baus (architecture critic, Stuttgart), Rolf Stroux (architect and member of the IBA's board of trustees), Matthis Bacht (artist, Heidelberg), and Hans-Jürgen Fuchs and Jörn Fuchs (chairs of the two community boards involved).

Source: Picture Archive IBA Heidelberg. Copyright: IBA Heidelberg, Valentina Meuren. Reprinted with permission.

The reverse strategy is implemented with the IBA_LABs, where examples of European best practice are presented to the public in Heidelberg and discussed with local users, stakeholders, and decision-makers as experts. In that forum issues such as innovative campus design, hybrids of working and housing, and potential in facilities for future research and development initiate knowledge transfers in many directions for administrators, educators, and researchers.

The IBA_ACADEMY takes a more distant, but also inspiring, look at Heidelberg. It enables students and faculty from international schools of architecture and planning (e.g., from Norway, Mexico, and Switzerland) to make Heidelberg their testing ground for ideas. Be it an entire neighborhood or certain institutions designed for innovation, a fresh view from the outside helps to increase receptiveness among different interest groups.

Last but not least, the IBA_SUMMIT aims for an international exchange among knowledge pearls. In this part of the IBA, mayors and university presidents (e.g., from Cambridge, England; Cambridge, Massachusetts in the United States; Leuven, Belgium; Lund, Sweden; and Stanford University in California) present their 


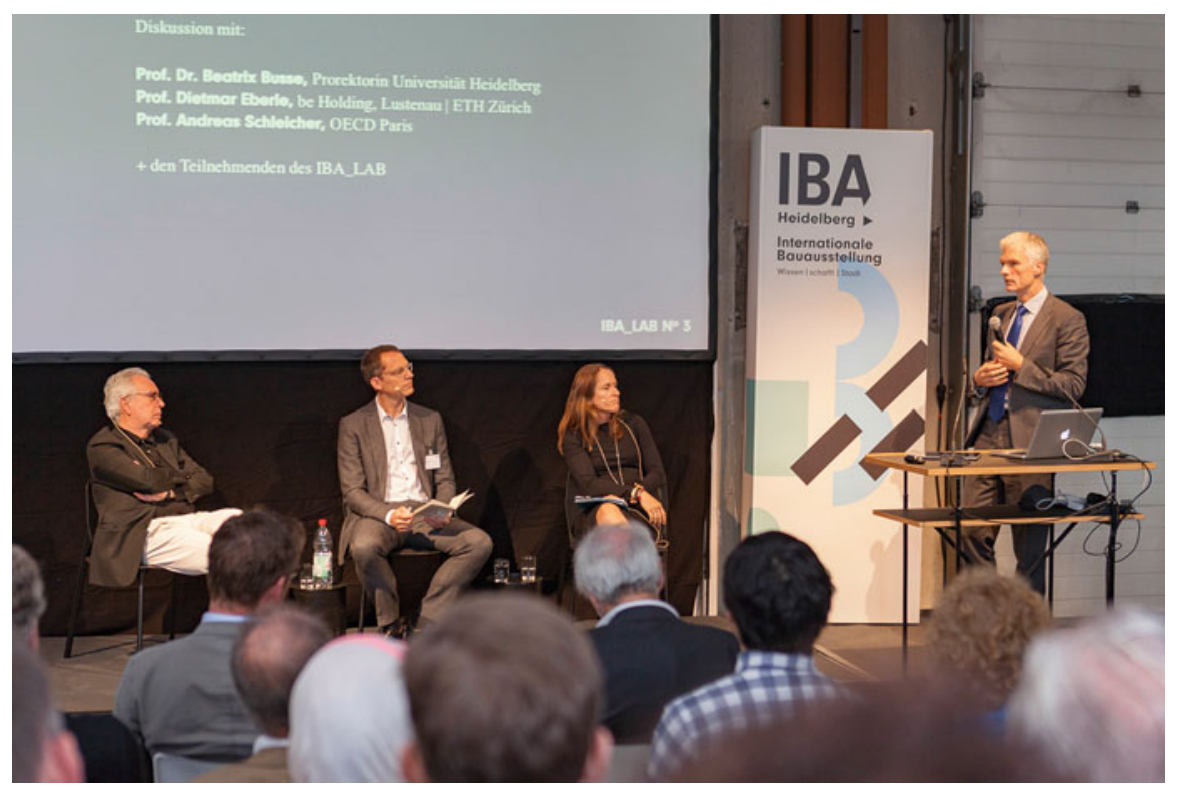

Fig. 14.4 IBA_LAB, No. 3-An interdisciplinary and international debate between planners and scientists about a next practice for buildings for academia, research, and development on October 7, 2015. Pictured on the podium are (from left to right) architect Dietmar Eberle (ETH, Zürich); moderator Carl Zillich (IBA, Heidelberg); linguist and vice president of Teaching Beatrix Busse (Heidelberg University); and (standing) Andreas Schleicher, director of the PISA Report, the Programme for International Student Assessment (OECD, Paris).

Source: Picture Archive IBA Heidelberg. Copyright: IBA Heidelberg, Iman Mohammadi. Reprinted with permission.

experience of "town-and-gown" relationships as a challenging, but necessary, basis for cocreating a future vision of a built environment beneficial to both aspects.

\section{Structure and Process}

For all that these discourses can do to help build a foundation for a long-term project such as an IBA, the crucial elements are the innovative projects and the processes leading to them. In this respect the IBA faces the same challenge as its sisters of recent years did: that of securing funding for the platform only, not the construction to result from it. Nevertheless, Heidelberg has set up a structure for eliciting engagement at different public levels and by private businesses and foundations.

The IBA office is organized as a limited liability corporation of the city. The executive board has a majority consisting of members of Heidelberg's city council and three external delegates. The board of trustees is exceptional in its engagement. It includes acclaimed professionals with international reputations in architecture, 


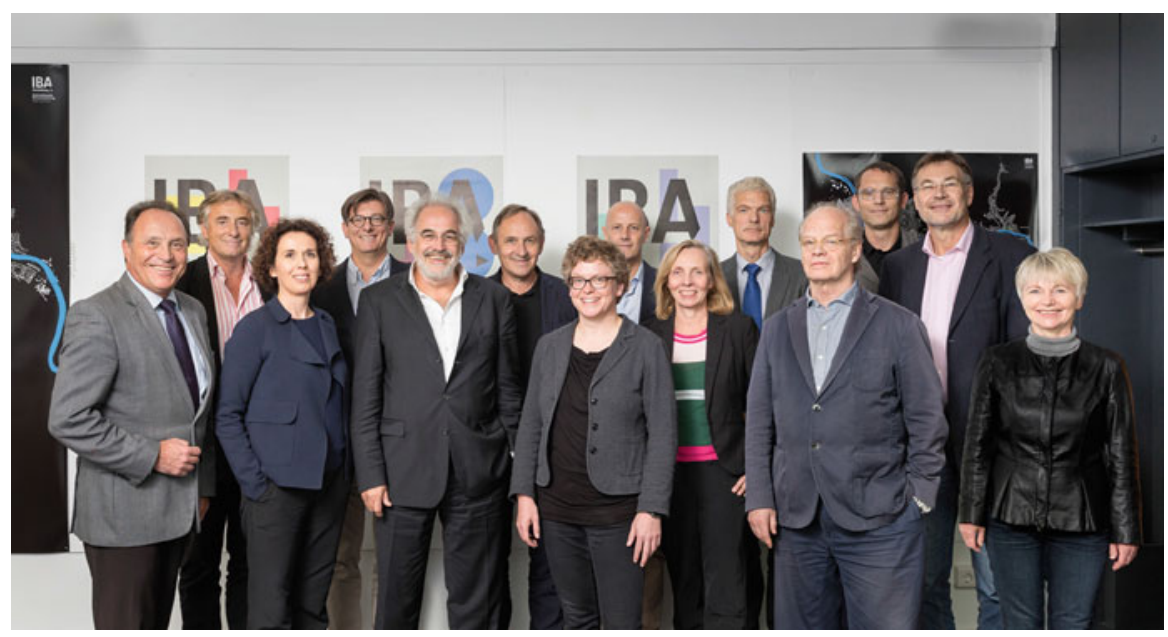

Fig. 14.5 The international and interdisciplinary board of trustees (without Iain M. Mattaj, Director General of European Molecular Biology Laboratory, Heidelberg) in 2015. From left to right: Bernd Müller (Public Real Estate, Germany), Ernst Hubeli (Urban Design, Switzerland), Angelika Fitz (Cultural Practice, Austria), Johan Deburchgrave (Economics, Belgium), Michael Braum (Director, IBA), Volker Staab (Architecture, Germany), Silke Steets (Sociology, Germany), Stephen Craig (Arts, Ireland), Undine Giseke (Chair, Landscape, Germany), Andreas Schleicher (Education Policy, France), Ulf Matthiesen (Anthropology, Germany), Carl Zillich (Curatorial Director, IBA), Siegfried Zedler (Teaching, Germany), and Annette Friedrich (Urban Planning, Germany). Source: Picture Archive IBA Heidelberg. Copyright: IBA Heidelberg, Christian Buck. Reprinted with permission.

planning, sociology, life sciences, business, and other fields (see Fig. 14.5). This interdisciplinary group advises the IBA office in its procedures and selection of projects. In the first year five criteria for projects worthy of the IBA were developed on the basis of the standards set forth by the federal commission around 2010:

1. Public Relevance: No self-referential building projects can be accepted.

2. Extra Competence: Processes and discourses should include the brightest minds available.

3. Prototype: The resulting project should include an experimental part.

4. Structural Impact: The project should contribute to its immediate surrounding and neighborhood.

5. Polyvalence: A degree of heterogeneity or mix of functions should be incorporated in order to foster the transfer of knowledge and to be open to future adaptations. 


\section{Candidates and Projects}

The IBA office is now also initiating projects with selected partners, but the basis for ideas remains an open call for projects, which was first announced in October 2013. Different formats for qualification and strategies for funding and realization are developed and applied by academic institutions, established associations, and engaged individuals. So far 26 candidates have benefited from an international network of advisors and strategic partners who help them clarify their contribution to the desired aspects of innovation, which are individually defined as well. Whereas some concepts focus on new spatial arrangements of functions, others diversify their program to expand the number of people or disciplines they can reach. Not all ideas will succeed on this path to a building project, for it is full of obstacles, especially for newcomers to the field of real-estate development. As of spring 2017, 16 candidates have met the IBA criteria (Fig. 14.6).

In 2015 four concepts were recommended by the board of trustees and designated by the board of administrators as official projects of the Heidelberg IBA. After treatment in workshops, elaboration of their concept, and, in some cases, creation of a reliable organizational structure, these former candidates were selected as being especially promising. One is an independent educational facility focusing on craftmanship as a neglected aspect of knowledge. Another project is about building a self-governed and collaborative student residence hall that offers academic guidance internally and externally through preparatory training and formats open to the general public. The municipality also has an IBA project through which a new building will house a kindergarten, an elementary school, and a community center and will foster the exchange between different generations and milieus. The fourth project is the reinvention of a museum for outsider art (art brut, or art by people with psychiatric experience), which offers the university hospital's department of psychiatry a unique interface with the public and makes an exhibition space and a discursive laboratory available to art researchers. Additional projects are under consideration for eligibility as IBA projects (Fig. 14.7), and recruitment of academic institutions and real-estate development is in progress to meet the challenge of a diversified approach to a knowledge-based urbanism. The first projects are to be completed in time for the interim exhibition in 2018, so most of the projects must be well advanced by then and completed by 2022 .

\section{Challenges for Heidelberg and IBAs in the Twenty-first Century}

Not every idea for a building project that is to be completed by 2022 has been assigned a location. The search for these sites ties into the ambitions to have the project concepts qualify for the Heidelberg IBA and secure funding for them. Parallel processes have resulted with each project, challenging established modes 


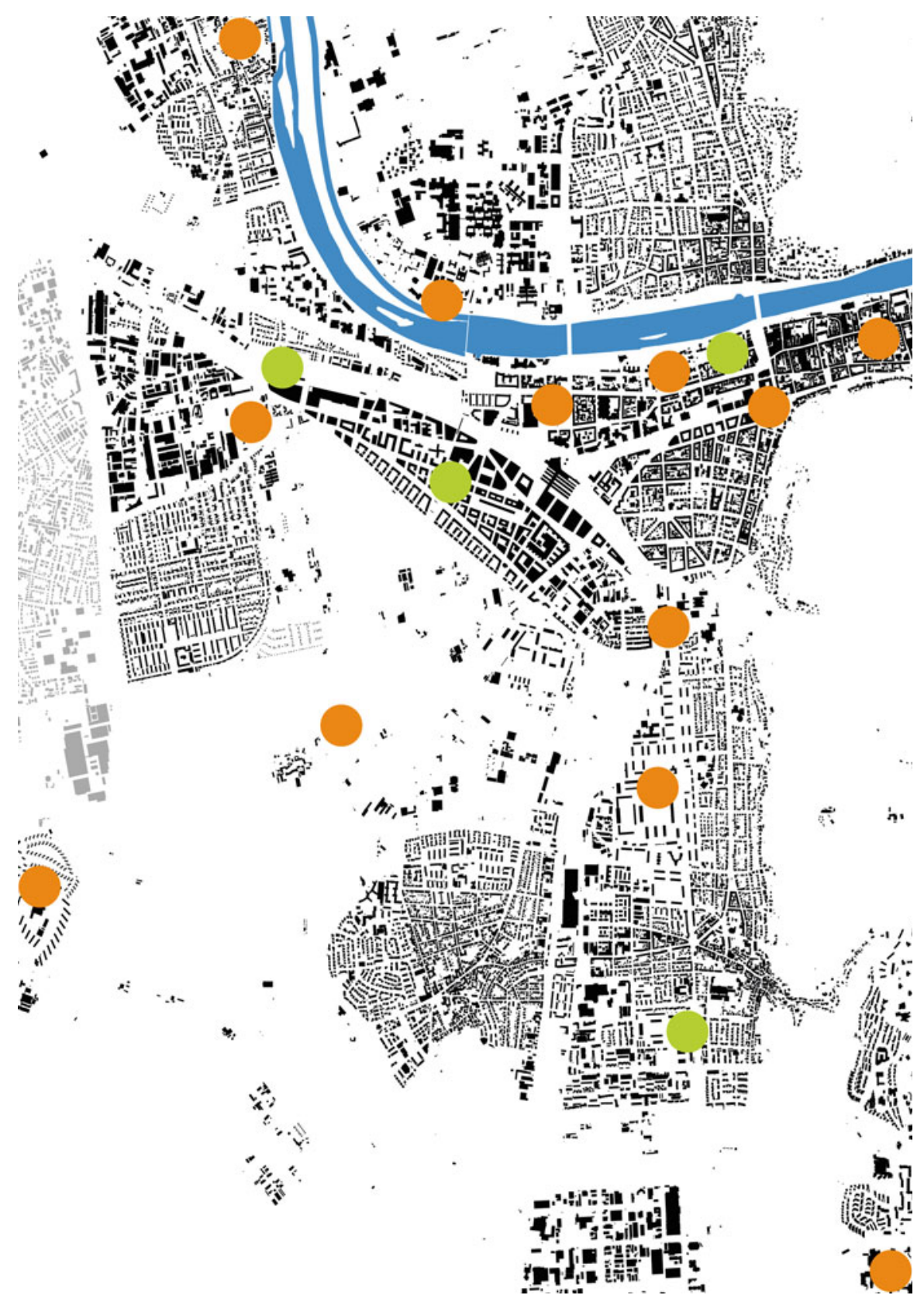

Fig. 14.6 Map of Heidelberg showing the anticipated location of some projects as of 2016 (orange: ideas; green: real projects under development with IBA support). The aim is to achieve spatial dispersal across Heidelberg and thereby bring catalysts of the knowledge-based society to each neighborhood and to different milieus.

Source and Copyright: IBA Heidelberg. Reprinted with permission. 


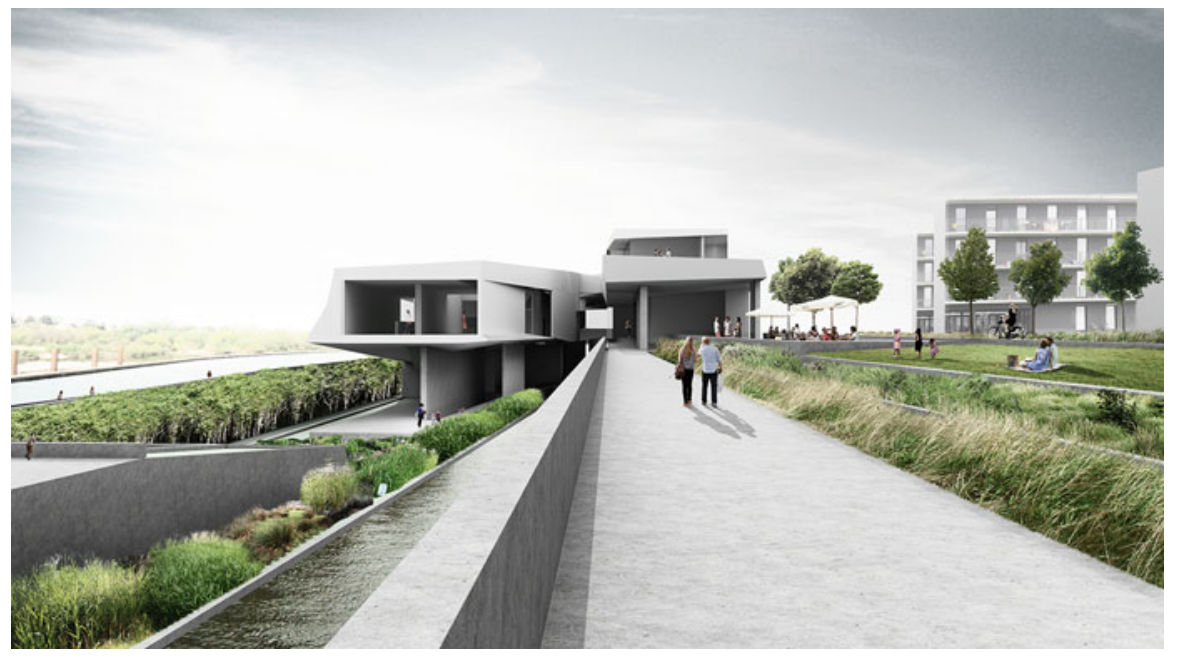

Fig. 14.7 A design concept for an as-yet unfunded IBA candidate project, "Center for Biodiversity," on the Neckar river alongside the campus Im Neuenheimer Feld (Filke, 2015). Illustrating the generation of hubs for transdisciplinary discourses in Heidelberg, the programming and spatial solutions offered by this design benefit scientist and nonscientist alike.

Source: Picture Archive IBA Heidelberg. Copyright: Thomas Harry Filke, TU Braunschweig. Reprinted with permission.

of cooperation between many stakeholders. Innovation in governance is therefore a crucial part of the IBA in Heidelberg. In the reality-based laboratory of the IBA, municipality and state and all other established stakeholders need to establish open models of cooperation.

In May 2016 the City of Heidelberg commissioned an experimental development process based on this agenda. The IBA conceived and directed four scenarios and one vision for development of the Patrick Henry Village (PHV) - the 100-hectare site of the former U.S. military housing compound-for up to 15,000 people to live and work. For one year the IBA office conducted a "planning-phase zero." Based on conceptual workshops (at SAP AppHaus, called "design thinking") with local and external advisors and on a subsequent collaborative planning process headed by architect Kees Christiaanse (Fig. 14.8), proposals for a future "knowledge city" now combine everyday life with facilities for research and development, innovative digital solutions, sustainable mobility, and experimental resource management.

Time will tell whether it is possible to improve the link between integrative strategic program development and the spatial practice of urban development by bringing together diverse actors from the corporate, scientific, and administrative worlds and society at large. Through ambitious planning processes and architecture, 


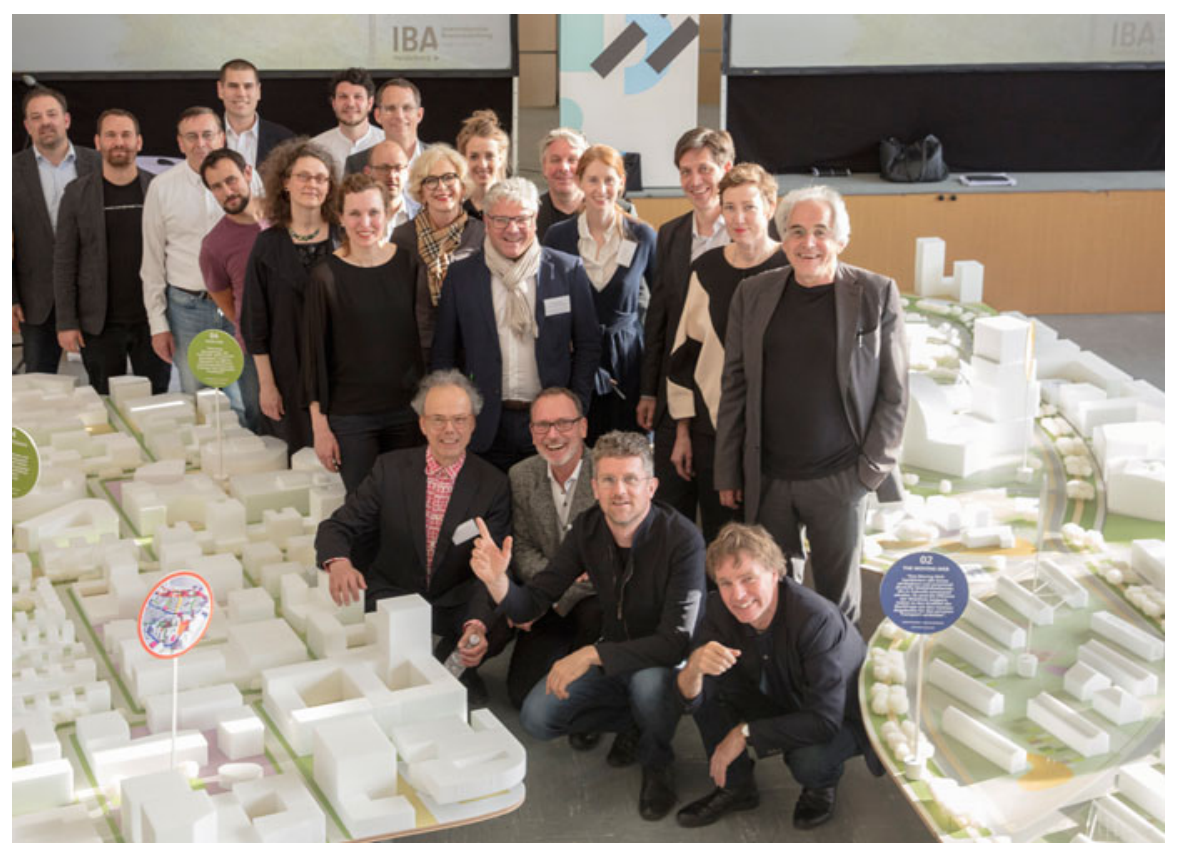

Fig. 14.8 IBA Heidelberg and Kees Christiaanse Architects \& Planners were responsible for the collaborative process involving many experts to shape the vision of a new Patrick Henry Village. Among them (front row): Kees Christiaanse (Rotterdam and Zürich, focus on overall urban design), Herbert Dreiseitl (Überlingen and Singapore, focus on urban metabolism), Carlo Ratti (Turin, and Cambridge, Massachusetts, focus on digitalization and mobility), and Winy Maas (Rotterdam and Delft, focus on the nexus of science and the corporate world). The group is gathered around a working model built to discuss the vision with the general public, stakeholders, and potential investors.

Source: Picture Archive IBA Heidelberg. Copyright: IBA Heidelberg, Christian Buck. Reprinted with permission.

the IBA serves as an "intermediary agent" (Selle, 2017, pp. 117-118) acting beyond existing paradigms, habits, and different point of views. Questions of densities and typologies also point out the need to engage with logics of real-estate development, both in the private and public sector, where a wide variety of regulations are still based on the modernistic paradigm of the separation of functions. Together with the need for cocreation in an existing city and society, the task has expanded to include the updating of procedures as well as of projects.

Ultimately, particular networks and windows of opportunity will determine the success of the Heidelberg IBA. Although many arrangements can be planned and executed, the lack of money for the necessary experiments calls for resilient 
innovation. Will there be public-private partnerships to benefit both ends in terms of content, not just profit? Is the middle ground between specialization and the commons a fruitful terrain for next practices in and for a new knowledge-based society? What the image and shape of Heidelberg will be in all its variety is an open question.

With a process stretching over more than 10 years, questions, not solutions, are on the table. This spirit of uncertainty alone is worth the endeavor. It is based on reflexive practice and destined to show how a knowledge pearl can change to meet the demands of, and deliver the integration for, a twenty-first century in which people want to work and live.

\section{References}

Burckhardt, L. (2015). Strollology: A minor subject. In conversation with Hans Ulrich Obrist. In M. von Ritter \& M. Schmitz (Eds.), Why is landscape beautiful? The science of strollology (pp. 7-16). Berlin: Birkhäuser, de Gruyter.

Durth, W. (2010a). Ein Memorandum zur Zukunft Internationaler Bauausstellungen: Zehn Empfehlungen zur Durchführung einer Internationalen Bauausstellung [A declaration on the future of international building exhibitions: Ten recommendations for putting on an international building exhibition]. In Internationale Bauausstellung IBA Hamburg (Ed.), Netzwerk IBA meets IBA: Zur Zukunft Internationaler Bauausstellungen (pp. 64-73). Berlin: Jovis.

Durth, W. (2010b). Eine Zeitreise durch die Baukultur: Zur Geschichte der Internationalen Bauausstellungen [A time travel through the Baukultur: On the history of international building exhibitions]. In Internationale Bauausstellung IBA Hamburg (Ed.), Netzwerk IBA meets IBA: Zur Zukunft Internationaler Bauausstellungen (pp. 16-31). Berlin: Jovis.

Filke, T. H. (2015). Das Bio-Center for Biodiversity Heidelberg [The Biocenter for Diversity, Heidelberg] (Unpublished master's thesis). Institute of Architectural Design (IAD), Technical University Braunschweig.

Hubber, P., \& Ramseger, J. (2017). Physical learning environments for science education: An ethnographic field study of primary classrooms in Australia, Germany and Taiwan. In M. Hackling, J. Ramseger, \& H.-L. S. Chen (Eds.), Quality teaching in primary science education: Cross-cultural perspectives (pp. 51-77). Cham: Springer.

Malaguzzi, L., \& Cagliari, P. (2016). Loris Malaguzzi and the schools of Reggio Emilia: A selection of his writings and speeches, 1945-1993. London: Routledge.

Matthiesen, U. (2015). Wissensgesellschaft und soziale Wissensstadt: Skizzen zu Kerndynamiken und neuen Arbeiten/Wohnen-Kopplungen in der Wissensstadt [The knowledge-based society and the social city of knowledge: Sketches of underlying dynamics and new links of working and living in the city of knowledge]. In Wüstenrot Stiftung (Ed.), ZukunftsWerkstattWohnbauen 2014: Polyvalente Konversion-Wohnen und Arbeiten in der Wissensstadt Heidelberg (pp. 12-29). Ludwigsburg: Wüstenrot Stiftung.

Selle, K. (2017). Making of . . Die ersten Jahre einer Internationalen Bauausstellung [The Making of ... The initial years of an international building exhibition]. In IBA Heidelberg (Ed.), Die Wissensstadt von morgen: Reflexionen (pp. 109-123). Zurich: Park Books. 
Stadt Heidelberg. (2012). Wissen schafft Stadt-Stadt schafft Wissen: Memorandum IBA Heidelberg. Perspektiven der Europäischen Stadt in der Wissensgesellschaft [Knowledge-based urbanism and urban-based knowledge: A memorandum by the Heidelberg IBA. Perspectives for the European city in the knowledge-based society]. Retrieved from http://www.heidelberg. de/site/Heidelberg_ROOT/get/documents_E1837061966/heidelberg/Objektdatenbank/61/PDF/ 61_pdf_IBA_Wissenschafftstadt_Memorandum.pdf

Van Winden, W., Van den Berg, L., \& Pol, P. M. J. (2007). European cities in the knowledge economy: Towards a typology. Urban Studies, 44, 525-549. doi: https://doi.org/10.1080/ 00420980601131886

Open Access This chapter is licensed under the terms of the Creative Commons Attribution 4.0 International License (http://creativecommons.org/licenses/by/4.0/), which permits use, sharing, adaptation, distribution and reproduction in any medium or format, as long as you give appropriate credit to the original author(s) and the source, provide a link to the Creative Commons license and indicate if changes were made.

The images or other third party material in this chapter are included in the chapter's Creative Commons license, unless indicated otherwise in a credit line to the material. If material is not included in the chapter's Creative Commons license and your intended use is not permitted by statutory regulation or exceeds the permitted use, you will need to obtain permission directly from the copyright holder. 